\title{
PENENTUAN DOSIS EFEKTIF EKSTRAK DAUN PACAR (Lawsonia inermis L.) SEBAGAI ANTIINFLAMASI
}

\author{
Selvi Megawati, Herman, Muhammad Amir Masruhim \\ Laboratorium Penelitian dan Pengembangan FARMAKA TROPIS, Fakultas Farmasi, Universitas \\ Mulawarman, Samarinda, Kalimantan Timur \\ email: selvi_subiantoro@yahoo.com
}

\begin{abstract}
Has been conducted a research of dose determination of effectiveness extract of Lawsonia inermis L. as anti-inflammatory on Rattus norvegicus. The purpose of this research is to gain an in depth understanding of effective dose of Lawsonia inermis L. as anti-inflammatory toward the reduction time of swelling on Rattus norvegicus' feet .The method which being used was carrageenan induced on Rattus norvegicus' feet. Rattus norvegicus were devided to 6 (six) group which a group as negative control was given sodium CMC orally, a group as positive control was given Sodium Diclofenac orally, and 4 (four) as test was given extract with 4 doses variation $(50 \mathrm{mg} / \mathrm{kg}, 100 \mathrm{mg} / \mathrm{kg}, 150 \mathrm{mg} / \mathrm{kg}$, and $200 \mathrm{mg} / \mathrm{kg}$ ) orally to each of mice that has pre-conditioned to swell on its foot. The result shows that T-Count is bigger than T-Table with significant standart 0,05 and smaller than T-Table with significant standart 0,01. It proves that there is significant difference between sodium diclofenac and extract of Lawsonia inermis $L$ in $100 \mathrm{mg} / \mathrm{kgBW}$. That concludes that extract of Lawsonia inermis L. has anti-inflammatory effect with effective dose as anti-inflammatory in $100 \mathrm{mg} / \mathrm{kg}$.
\end{abstract}

Keywords : Lawsonia inermis L., Anti-inflammatory., Rattus norvegicus.

\begin{abstract}
Abstrak
Telah dilakukan penelitian penentuan dosis efektif ekstrak daun pacar (Lawsonia inermis L.) sebagai antiinflamasi pada tikus putih (Rattus norvegicus). Penelitian ini bertujuan untuk mengetahui dosis ekstrak daun pacar yang efektif sebagai antiinflamasi terhadap waktu penurunan bengkak pada kaki tikus putih. Metode yang digunakan yaitu induksi karagenan pada kaki tikus putih. Tikus putih dikelompokkan menjadi 6 kelompok yaitu kelompok kontrol negatif diberikan natrium CMC, kelompok kontrol positif diberikan natrium diklofenak dan 4 kelompok uji diberikan ekstrak dengan 4 variasi dosis yaitu $50 \mathrm{mg} / \mathrm{kg}, 100$ $\mathrm{mg} / \mathrm{kg}, 150 \mathrm{mg} / \mathrm{kg}$ dan $200 \mathrm{mg} / \mathrm{kg}$ yang masing-masing diberikan secara oral dan tiap kaki tikus dikondisikan bengkak terlebih dahulu. Hasil penelitian ini membuktikan ekstrak daun pacar memiliki kemampuan sebagai antiinflamasi dengan dosis efektif $100 \mathrm{mg} / \mathrm{kgBB}$.
\end{abstract}

Kata Kunci: Lawsonia inermis L., Antiinflamasi, Rattus norvegicus.

\section{PENDAHULUAN}

Indonesia memiliki kekayaan tumbuhan yang luar biasa. Dari 300.000 spesies tumbuhan yang ada, sekitar 1.260 spesies dapat dimanfaatkan sebagai obat. Seiring dengan makin maraknya gaya hidup back to nature, semakin gencar pula penelitian tentang kandungan dan manfaat tanamantanaman tersebut (Mangan, 2009). Penggunaan obat tradisional yang berasal dari tumbuhan banyak dikembangkan 
terutama dibidang kesehatan berdasarkan indikasi tumbuhan yang telah digunakan sebagian masyarakat dengan khasiat yang teruji secara empiris.

Tumbuhan pacar (Lawsonia inermis L.) terutama bagian daun merupakan salah satu tumbuhan yang sudah dikenal masyarakat sebagai obat bengkak yang sering terjadi karena jatuh dan terbentur benda keras. Secara empris pemanfaatannya dengan cara ditumbuk halus dan ditempelkan pada bagian yang bengkak. Bengkak yang terjadi biasanya disertai dengan kemerahan, panas dan rasa nyeri. Tanda-tanda ini menunjukan terjadinya inflamasi. Inflamasi merupakan suatu respon protektif normal terhadap luka jaringan yang disebabkan oleh trauma fisik, zat kimia yang merusak atau zat-zat mikrobiologik. Inflamasi adalah usaha tubuh untuk menginaktivasi atau merusak organisme yang menyerang, menghilangkan zat iritan dan mengatur derajat perbaikan jaringan (Mycek, Harvey dan Champe, 1997).

Daun pacar berbentuk bulat panjang dengan pangkal runcing, panjang 2-3 cm dan lebar 1-2 cm (Muhammad, 2005) serta memiliki kandungan beberapa metabolit sekunder yaitu flavanoid, lawsone, tanin dan saponin (Zafar, dkk, 2006). Berbagai kandungan pada daun pacar tersebut yang diperkirakan sebagai antiinflamasi adalah flavanoid. Menurut Robinson (1991) flavanoid dapat mengobati inflamasi karena dapat menghambat kerja dari salah satu mediator radang yaitu prostaglandin.

Selain itu, menurut penelitian yang telah dilakukan oleh Caudhary di Rayat and Bahra College of Pharmacy, Hoshiarpur, Punjab, India (2010) bahwa daun pacar memiliki aktivitas sebagai analgesik dan antiinflamasi. Berdasarkan uraian di atas, dilakukan penelitian untuk mengetahui dosis efektif ekstrak daun pacar sebagai antiinflamasi dengan menguji pada hewan coba yaitu tikus putih yang telah dikondisikan bengkak.

\section{METODE PENELITIAN}

\section{Bahan}

Daun pacar (Lawsonia inermis L.), etanol $80 \%$, aquades, natrium CMC, natrium diklofenak dan karagenan.

\begin{abstract}
Alat
Spoid (Terumo), sonde, gelas kimia (Pyrex $\left.{ }^{\circledR}\right)$, labu ukur (Pyrex ${ }^{\circledR)}$, batang pengaduk, cawan porselin, timbangan digital (Mettler Toledo), benang, toples kaca, corong, water bath, rotary evaporator $\left(E Y E L A^{O S B-2100}\right)$ dan desikator.
\end{abstract}

\section{Prosedur Penelitian}

Tikus putih yang digunakan sebanyak 18 ekor yang dibagi menjadi 6 kelompok, masing-masing kelompok terdiri dari 3 ekor tikus putih. Kelompok pertama merupakan kelompok negatif dengan pemberian natrium CMC, kelompok kedua merupakan kelompok kontrol positif dengan pemberian natrium diklofenak, kelompok tiga sampai enam merupakan kelompok uji dengan pemberian ekstrak daun pacar. Kelompok uji diberikan dosis dengan berbagai variasi dosis yaitu 50 $\mathrm{mg} / \mathrm{kgBB}, 100 \mathrm{mg} / \mathrm{kgBB}, 150 \mathrm{mg} / \mathrm{kgBB}$ dan $200 \mathrm{mg} / \mathrm{kgBB}$. Pemberian natrium CMC, natrium diklofenak dan ekstrak dilakukan secara oral dengan terlebih dahulu mengkondisikan tikus putih dalam keadaan bengkak pada kaki tikus. Kondisi bengkak pada kaki tikus dilakukan dengan metode induksi karagenan, karagenan 1\% disuntikkan secara intraplantar sebanyak 
0,1 mL pada kaki tikus putih kemudian dilakukan pengukuran diameter kaki tikus yang mengalami bengkak. Penyuntikan intraplantar dilakukan setelah 30 menit pemberian ekstrak daun pacar secara oral. Sedangkan, pengukuran diameter kaki tikus yang bengkak dimulai setelah 30 menit penyuntikkan karagenan pada kaki tikus putih.

\section{HASIL DAN PEMBAHASAN}

Hasil penelitian dengan menggunakan berbagai variasi dosis ekstrak daun pacar terhadap tikus putih yang sebelumnya disuntikkan secara intraplatar karagenan menunjukkan bahwa ekstrak daun pacar memiliki efek sebagai antiinflamasi. Setiap dosis memiliki efek penurunan bengkak yang berbeda tiap waktu pengukuran. Hal tersebut diketahui dengan membandingkan ekstrak daun pacar terhadap NaCMC $1 \%$ sebagai kontrol negatif. Dilakukan 4 variasi dosis untuk mengetahui efektivitas antiinflamasi yaitu $50 \mathrm{mg} / \mathrm{kgBB}, \quad 100 \mathrm{mg} / \mathrm{kgBB}, \quad 150$ $\mathrm{mg} / \mathrm{kgBB}$ dan $200 \mathrm{mg} / \mathrm{kgBB}$. Diperoleh hasil bahwa dosis $100 \mathrm{mg} / \mathrm{kgBB}$ memberikan efek antiinflamasi lebih baik dibandingkan dengan ketiga dosis lainnya yang terlihat pada waktu penurunan bengkak yang lebih cepat. Hal ini terlihat pada tabel 1 .

Kontrol negatif yang menggunakan NaCMC $1 \%$ semakin bengkak dari waktu ke waktu. Waktu 390 menit terlihat cenderung pembengkakan berhenti dan menurun hingga 480 menit. Dibandingkan dengan dosis ekstrak daun pacar yaitu dosis $50 \mathrm{mg} / \mathrm{kgBB}$ mulai terjadi penurunan pada waktu 270 menit, dosis $100 \mathrm{mg} / \mathrm{kg}$ pada waktu 210 menit, dosis 150 dan 200 $\mathrm{mg} / \mathrm{kg}$ pada waktu 330 menit. Hasil pengujian tersebut juga diperjelas dengan memperhatikan gambar 1.

Tabel 1. Hasil pengujian variasi dosis ekstrak etanol daun pacar

\begin{tabular}{cccccccccccc}
\hline \multirow{3}{*}{ Perlakuan } & $\begin{array}{l}\text { Diameter } \\
\text { rata-rata } \\
\text { Kaki Tikus }\end{array}$ & \multicolumn{1}{c}{ Diameter rata-rata kaki tikus pada waktu (t) menit (Dt) } \\
& Do & Db & $\mathbf{3 0}$ & $\mathbf{9 0}$ & $\mathbf{1 5 0}$ & $\mathbf{2 1 0}$ & $\mathbf{2 7 0}$ & $\mathbf{3 3 0}$ & $\mathbf{3 9 0}$ & $\mathbf{4 5 0}$ & $\mathbf{4 8 0}$ \\
\hline Kontrol Negatif & 2 & 2,5 & 2,5 & 2,6 & 2,7 & 2,8 & 2,97 & 3,1 & 3,1 & 3,03 & 2,97 \\
$50 \mathrm{mg} / \mathrm{kgBB}$ & 2 & 2,5 & 2,5 & 2,6 & 2,67 & 2,77 & 2,57 & 2,5 & 2,4 & 2,3 & 2,2 \\
$100 \mathrm{mg} / \mathrm{kgBB}$ & 2 & 2,4 & 2,5 & 2,6 & 2,7 & 2,6 & 2,57 & 2,47 & 2,3 & 2,2 & 2,1 \\
$150 \mathrm{mg} / \mathrm{kgBB}$ & 2 & 2,5 & 2,5 & 2,6 & 2,67 & 2,77 & 2,77 & 2,6 & 2,5 & 2,4 & 2,3 \\
$200 \mathrm{mg} / \mathrm{kgBB}$ & 2,1 & 2,6 & 2,6 & 2,7 & 2,8 & 2,87 & 2,9 & 2,7 & 2,7 & 2,6 & 2,5 \\
\hline
\end{tabular}

Keterangan :

Do

: Diameter awal kaki tikus $\quad$ Diameter $\quad$ :Dalam satuan $\mathrm{cm}$

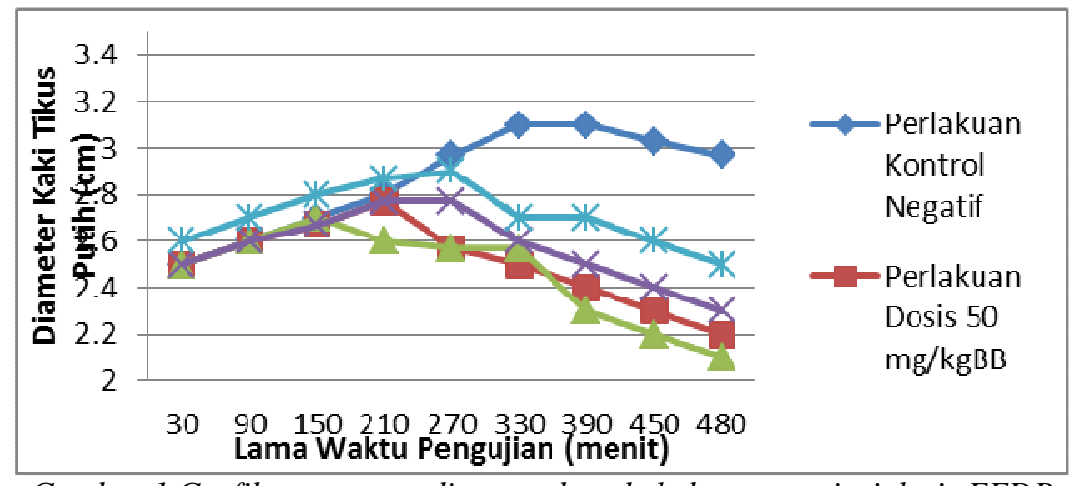

Gambar 1 Grafik penurunan diameter bengkak dengan variasi dosis EEDP 
Penentuan Dosis Efektif Ekstrak Daun Pacar (Lawsonia inermis L.) Sebagai Antiinflamasi

Tabel 2. Persen penghambatan radang pada kaki tikus putih

\begin{tabular}{ccccccccccc}
\hline $\begin{array}{c}\text { Dosis } \\
\text { Perlakuan } \\
\text { (mg/kgBB) }\end{array}$ & $\mathbf{3 0}$ & $\mathbf{9 0}$ & $\mathbf{1 5 0}$ & $\mathbf{2 1 0}$ & $\mathbf{2 7 0}$ & $\mathbf{3 3 0}$ & $\mathbf{3 9 0}$ & $\mathbf{4 5 0}$ & $\mathbf{4 8 0}$ & Rata-rata \\
\hline 50 & 25 & 30 & 33,5 & 38,5 & 28,5 & 25 & 20 & 15 & 10 & 25,1 \\
100 & 25 & 30 & 35 & 30 & 28,5 & 23,5 & 15 & 10 & 5 & 22,4 \\
150 & 25 & 30 & 33,5 & 38,5 & 38,5 & 30 & 25 & 20 & 15 & 28,4 \\
200 & 23,8 & 28,6 & 33,3 & 36,7 & 38,1 & 28,6 & 28,6 & 23,8 & 19 & 29 \\
\hline
\end{tabular}

Tabel 3. Hasil analisis ANOVA 2 arah

\begin{tabular}{lcccccc}
\hline $\begin{array}{l}\text { Sumber } \\
\text { Variansi }\end{array}$ & Db & $\begin{array}{c}\text { Jumlah } \\
\text { kuadrat }\end{array}$ & KT & FHitung & \multicolumn{2}{c}{ Tabel } \\
\hline Dosis & 4 & 2,92 & 0,73 & $73^{* *}$ & 2,4729 & 3,5350 \\
Waktu & 8 & 1,61 & 0,20 & $20^{* *}$ & 2,0430 & 2,7154 \\
Dosis $x$ & 32 & 4,70 & 0,0625 & $6,25^{* *}$ & 1,5720 & 1,8924 \\
Waktu & 90 & 1,1 & 0,01 & & & \\
Galat & 134 & 10,33 & & & & \\
Total & & & & &
\end{tabular}

Keterangan:

*: Signifikan

** : Sangat signifikan

Seluruh dosis memberikan kemampun penurunan bengkak namun jika dihubungkan dengan kecepatan penurunan bengkak terdapat dosis yang lebih cepat dalam menurunkan bengkak yaitu dosis $100 \mathrm{mg} / \mathrm{kg}$. Selanjutnya dilakukan perhitungan persen penghambatan radang untuk mengetahui besarnya penghambatan ditiap waktu pengukuran. Hasil perhitungan penghambatan persen radang dapat terlihat pada Tabel 2.

Berdasarkan Tabel 2 diketahui semua variasi dosis memberikan efek penghambatan radang dengan parameter persen penghambatan radang. Kemudian dilakukan perhitungan untuk mengetahui efektifitas ekstrak daun pacar antara dosis ekstrak daun pacar dengan waktu penurunan bengkak melalui uji statistik ANOVA 2 (dua) arah. Hasil statistik dapat dilihat pada Tabel 3.

Hasil uji ANOVA 2 (dua) arah pada Tabel 2 menunjukan bahwa F-Hitung lebih besar dari F-Tabel pada tingkat kepercayaan 95 dan 99. Hal ini membuktikan bahwa setiap variasi dosis daun pacar memiliki kemampuan signifikan dalam menghambat pembentukan radang. Kemudian dilakukan uji lanjutan untuk mengetahui dosis yang efektif untuk menghambat pembentukan radang. Penentuan uji lanjutan diawali dengan melakukan perhitungan Koefisien Keseragaman (KK). Hasil perhitungan KK menunjukan bahwa uji lanjutan yang sesuai yaitu uji Beda Nyata Jujur Duncan (BNJD)

Hasil BNJD menunjukkan adanya perbedaan yang signifikan dan sangat signifikan antara dosis esktrak daun pacar yang berarti bahwa adanya perbedaan nyata pada tiap dosis ekstrak daun pacar dalam memberikan efektifitas sebagai antiinflamasi. Selain itu terlihat bahwa dosis $100 \mathrm{mg} / \mathrm{kgBB}$ memiliki perbedaan signifikan dan sangat signifikan terhadap dosis $50 \mathrm{mg} / \mathrm{kgBB}$ dan $150 \mathrm{mg} / \mathrm{kgBB}$. Sehingga dosis $100 \mathrm{mg} / \mathrm{kgBB}$ yang paling efektif sebagai antiinflamasi dan hal tersebut juga terlihat pada diameter pembengkakan kaki tikus yang lebih kecil. 
Hasil uji BNJD untuk waktu menunjukkan adanya perbedaan yang tidak signifikan, signifikan dan sangat signifikan. Hasil tidak signifikan menunjukan tidak adanya perbedaan nyata antara waktu pengukuran terhadap diameter kaki tikus putih. Sedangkan signifikan dan sangat signifikan menunjukkan adanya perbedaan nyata antara waktu pengukuran dengan diameter kaki tikus putih. Pada waktu ke menit 210 menunjukkan hasil signifikan dibandingkan dengan waktu ke menit 150 dan menit ke 270. Hal ini menunjukkan bahwa waktu ke 210 menit ekstrak daun pacar sudah mulai mampu menurunkan bengkak terhadap kaki tikus yang ditunjukkan dengan diameternya.

Hasil dari pengujian natrium diklofenak yang kemudian dibandingkan dengan ekstrak daun pacar dengan dosis terbaik yaitu $100 \mathrm{mg} / \mathrm{kgBB}$. Perbandingan ini dimaksudkan untuk mengetahui kemampuan atau potensi ekstrak daun pacar untuk penghambatan radang antara dosis ekstrak etanol daun pacar $100 \mathrm{mg} / \mathrm{kgBB}$ dengan natrium diklofenak. Perbandingan dosis ekstrak etanol daun pacar $100 \mathrm{mg} / \mathrm{kgBB}$ dan natrium diklofenak dapat dilihat pada tabel 4.

Tabel 4. Hasil pengukuran diameter kaki tikus putih dengan pemberian ekstrak etanol daun pacar dan natrium diklofenak

\begin{tabular}{ccc}
\hline Waktu (Menit) & $\begin{array}{c}\text { Kontrol Positif } \\
\text { Natrium Diklofenak }\end{array}$ & $\begin{array}{c}\text { Dosis } \\
\mathbf{1 0 0 ~} \mathbf{~ m}\end{array}$ \\
\hline 30 & 2,43 & 2,5 \\
90 & 2,5 & 2,6 \\
150 & 2,4 & 2,73 \\
210 & 2,27 & 2,63 \\
270 & 2,13 & 2,57 \\
330 & 2 & 2,47 \\
390 & 1,97 & 2,33 \\
450 & 1,97 & 2,23 \\
480 & 1,97 & 2,07 \\
\hline
\end{tabular}

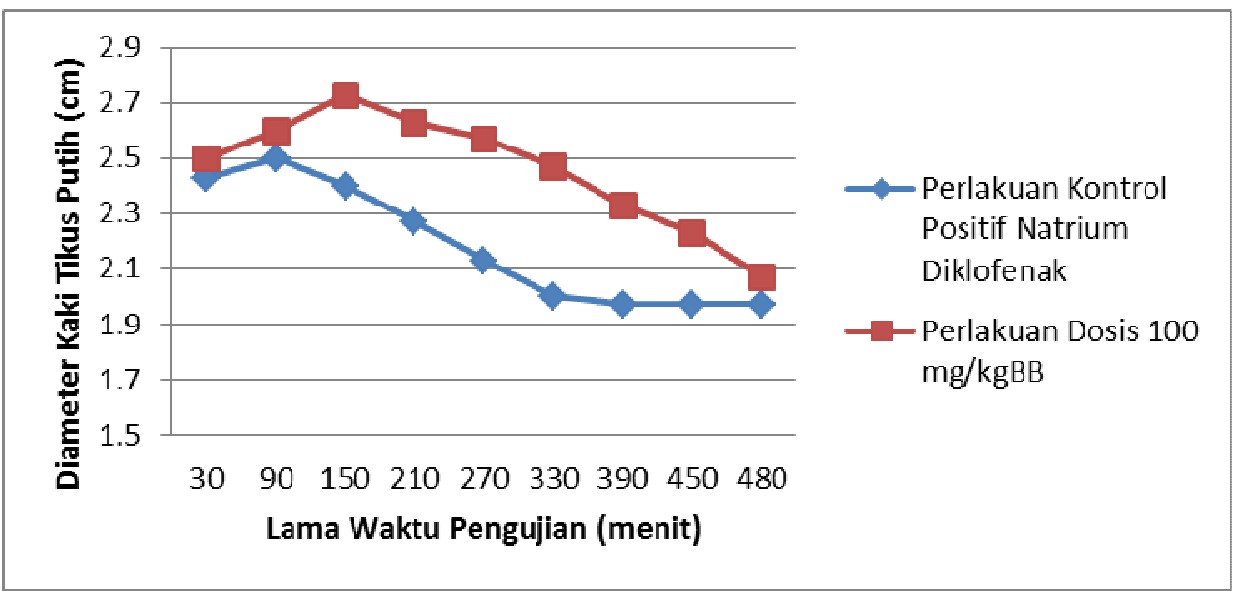

Gambar 2. Grafik perbandingan penurunan diameter kaki tikus putih antara pemberian EEDP dosis 100 $\mathrm{mg} / \mathrm{kgBB}$ dengan natrium diklofenak 
Hasil pengukuran diameter kaki tikus putih seperti yang tertera pada tabel di atas, bahwa obat sintetik yaitu natrium diklofenak lebih baik memberikan efek penghambatan radang dibandingkan ekstrak etanol daun pacar. Perbandingan antara natrium diklofenak dan ektrak etanol daun pacar dapat dilihat pada gambar 2.

Hasil pengujian pada ekstrak daun pacar dosis $100 \mathrm{mg} / \mathrm{kgBB}$ mulai terjadi penurunan bengkak pada waktu 210 menit sedangkan pada natrium diklofenak penurunan bengkak terjadi pada waktu 150 menit. Penurunan diameter pada kaki tikus putih dengan pemberian natrium diklofenak dimulai pada 150 menit dan berakhir pada 390 menit yang ditandai dengan diameter kaki tikus putih yang kembali seperti diameter awal sebelum diinduksi karagenan.

Uji perbandingan antara natrium diklofenak dan dosis efektif ekstrak daun pacar menggunakan uji t. Hasil uji $t$ dengan taraf signifikan 0,05 dan 0,01 yaitu t-hitung lebih besar dari t-tabel dengan taraf signifikan 0,05 dan lebih kecil dari ttabel dengan taraf signifikan 0,01 . Artinya ada perbedaan yang signifikan antara natrium diklofenak dengan ekstrak daun pacar dosis $100 \mathrm{mg} / \mathrm{kgBB}$.

Ekstrak daun pacar memiliki kemampuan penghambatan radang lebih rendah dibanding natrium diklofenak, namun apabila ekstrak daun pacar dibandingkan dengan NaCMC sebagai kontrol negatif maka ekstrak daun pacar memiliki kemampuan penghambatan radang.

\section{KESIMPULAN}

Ekstrak daun pacar memiliki efektifitas sebagai antiiflamasi dan dosis efektif ekstrak daun pacar sebagai antiinflamasi adalah $100 \mathrm{mg} / \mathrm{kg}$.

\section{UCAPAN TERIMAKASIH}

Penulis mengucapkan terimakasih kepada Kepala Laboratorium Penelitian dan Pengembangan FARMAKA TROPIS, Fakultas Farmasi atas izin dan bimbingannya melaksanakan penelitian. Terima kasih kepada para laboran atas bantuan dan kerjasamanya selama penelitian.

\section{DAFTAR PUSTAKA}

1. Caudhary, G. 2010. Lawsonia inermis Linnaeus, Phytopharmacological Review. International Journal of Pharmaceutical Sciences and Drug Research , 2010; 2(2). p 91-98.

2. Mangan, Y. 2009. Solusi Sehat Mencegah dan Mengatasi Kanker. PT. Agromedia Pustaka : Jakarta.

3. Muhammad, H.S; \& H. Muhammad. 2005. The Use of Lawsonia inermis Linn. (Henna) in the management of burn wound infections. African Journal of Biotechnology, 2005; Vol 4 (9), pp. 934-937.

4. Mycek, M.J.; Richard, A.H.; \& Pamela, C.C. 1997. Farmakologi Ulasan Bergambar. Terjemahan oleh Azwar Agoes. 2001. Widya Medika : Jakarta.

5. Robinson, T. 1991. Kandungan Organik Tumbuhan Tinggi. Terjemahan oleh Kosasih Padmawinata. 1995. ITB : Bandung.

6. Zafar, S.; Shoaib, A.; \& Shibli, J. 2006. Medicinal Plants, Traditional Knowledge. Uphaar Cinema Market : New Delhi. 